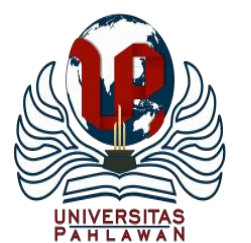

Jurnal Abdidas Volume 2 Nomor 5 Tahun 2021 Halaman 1115 - 1119

JURNAL ABDIDAS

http://abdidas.org/index.php/abdidas

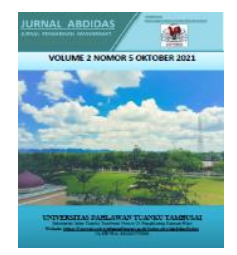

\title{
Pelatihan Pembuatan Soal dengan Google Drive untuk Pembelajaran Jarak Jauh
}

\author{
Anita Debora Br. Simangunsong ${ }^{\bowtie}$ \\ Pendidikan Kimia, Universitas HKBP Nommensen Pematangsiantar, Indonesia \\ E-mail : anitadebora715@gmail.com
}

\begin{abstract}
Abstrak
Salah satu dampak dari pandemi covid-19 ini adalah terjadi transformasi media pembelajaran yang dulu lebih banyak menggunakan sistem tatap muka di dalam kelas kini menjadi sistem online. Dengan adanya kebijakan ini membuat seluruh guru melakukan pembelajaran jarak jauh. Karena kebijakan ini muncul lah permasalahan yang diakibatkan tidak semua guru mahir menggunakan teknologi internet untuk penunjang kegiatan pembelajaran online dan perlu pendampingan dan pelatihan terlebih dahulu. Salah satu fitur keren yang ditujukan untuk dunia pendidikan di Google Drive adalah adanya fitur pembuatan kuis yang bisa di setting pada penggunaan google formulir dengan batasan waktu. Pengabdian masyarakat bertujuan untuk meningkatkan wawasan dan keterampilan guru dalam menggunakan aplikasi google form sebagai media pembelajaran jarak jauh. Adapun mitra yang terlibat ialah guru-guru di SMK Yapim Sei Rotan. Metode pelaksanaan kegiatan ini dilaksanakan menggunakan media online. Kegiatan adalah sosialisasi pelatihan dalam bentuk tutorial dan diskusi bagaimana membuat media kuis online menggunakan aplikasi google form. Sosialisasi dilakukan dengan tujuan memperkenalkan apa itu google form, bagaimana kelebihan google form dan bagaimana pemanfaatannya. Hasil kegiatan menunjukkan bahwa peserta pelatihan sudah memahami prinsip-prinsip menciptakan kuis dan mampu menciptakan kuis online menggunakan aplikasi Google. Hasil kegiatan diraskan manfaatnya bagi guru-guru serta keberhasilan kegiatan pengabdian ini dalam katergori berhasil.
\end{abstract}

Kata kunci: google drive, google form, pembelajaran jarak jauh

\begin{abstract}
One of the impacts of the COVID-19 pandemic is the transformation of learning media that used to use more face-to-face systems in the classroom to now become online systems. With this policy, all teachers undertake distance learning. Because of the policy, problems arose caused not all teachers were proficient in using internet technology to support online learning activities and needed assistance and training first. One of the cool features aimed at education on Google Drive is the quiz creation feature that can be set on the use of Google forms with a time limit. The society service aims increase insight and skills of teachers in using the Google Form application as distance learning media of learning. The partners involved are teachers at SMK Yapim Sei Rotan. The method of implementing this activity is carried out using online media. Activities are socialization training in the form of tutorials and discussions about steps to create online quiz media using the Google Form application. Socialization is done with the aim of introducing what is google form, how the advantages of google form and how to use it. The results of the activity showed that the trainees understood the principles of creating quizzes and were able to create online quizzes using Google applications. The results of the activity are considered to be of benefits for teachers as well as the success of this community service activity in the category of success.
\end{abstract}

Keywords: google drive, google form, distance learning

Copyright (c) 2021 Anita Debora Br. Simangunsong

$\triangle$ Corresponding author

Address : Universitas HKBP Nommensen Pematangsiantar

Email : anitadebora715@gmail.com

DOI : https://doi.org/10.31004/abdidas.v2i5.435

ISSN 2721- 9224 (Media Cetak)

ISSN 2721- 9216 (Media Online) 
1116 Pelatihan Pembuatan Soal dengan Google Drive Untuk Pembelajaran Jarak Jauh - Anita Debora Br. Simangunsong

DOI: https://doi.org/10.31004/abdidas.v2i5.435

\section{PENDAHULUAN}

Salah satu dampak dari pandemi covid-19 ini adalah terjadi transformasi media pembelajaran yang dulu lebih banyak menggunakan sistem tatap muka di dalam kelas kini menjadi sistem online. Pembelajaran jarak jauh di masa pandemi menimbulkan berbagai tanggapan dan perubahan pada sistem belajar yang dapat mempengaruhi proses pembelajaran serta tingkat perkembangan peserta didik dalam merespon materi yang disampaikan (Basar et al., 2021). Pembelajaran jarak jauh seperti yang sering kita dengar merupakan pembelajaran yang mengutamakan kemandirian. Sehingga dibutuhkan kesadaran dalam penggunaan media teknologi dengan memakai aplikasi media sosial yang sesuai dengan kebutuhan zaman dan kesesuaian kondisi pembelajaran. Menurut Prawiyogi dan Purwanugraha dalam penelitiannya, pembelajaran jarak jauh efektif dilakukan terhadap siswa SDIT Cendekia Purwakarta (Prawiyogi \& Purwanugraha, n.d.).

Pendidik dapat melakukan pembelajaran bersama di waktu yang sama menggunakan aplikasi media sosial seperti WhatsApp (WA), instagram, facebook, aplikasi zoom, google classroom, ataupun media aplikasi lainnya sebagai media pembelajaran. Pembelajaran yang efektif adalah pembelajaran yang dapat memanfaatkan teknologi informasi dan komunikasi dengan optimal sebagai alat bantu (Hanum, 2013).

Kegiatan pelatihan ini melibatkan guru-guru SMK Yapim Taruna Sei Rotan sebagai peserta. Berdasarkan hasil analisis kebutuhan mitra yang kami peroleh dari hasil wawancara dengan pihak mitra (kepala sekolah), maka diperoleh beberapa infromasi. Hasil wawancara tersebut kami dapatkan dari mitra yaitu tentang kendala yang dialami oleh guru-guru ketika melaksanakan proses Pembelajaran Jarak Jauh/Daring pada masa pandemi saat ini. Mitra mengalami kesulitan untuk membuat media evaluasi terhadap hasil dari proses pembelajaran jarak jauh ini, karena rata-rata guru menggunakan media pembelajaran WAG/WhatsApp group. Hal ini dikarenakan sumber daya manusia yaitu guru-guru yang mengajar di sekolah mitra belum memiliki banyak pengetahuan tentang pengembangan media pembelajaran secara online seperti saat ini.

Salah satu fitur keren yang ditujukan untuk dunia pendidikan di Google Drive adalah adanya fitur pembuatan kuis yang bisa di setting pada penggunaan google formulir dengan batasan waktu. Dengan adanya fitur ini tentunya akan sangat membantu guru-guru di dunia dalam melakukan evaluasi materi-materi yang telah disampaikan ke peserta didik. Adapun beberapa fungsi google form adalah sebagai berikut: 1) memberikan tugas latihan/online melalui laman website 2) mengumpulkan pendapat orang lain melalui laman website, 3) mengumpulkan berbagai data siswa melalui halamann website, 4) membuat formular pendaftaran online untuk sekolah, 5) membagikan kuesioner kepada orang-orang secara online. Pengabdian yang sudah dilakukan sebelumnya oleh Marlina,dkk (Marlina et al., n.d.) pelatihan model pembelajaran jarak jauh dengan google form dimana peserta mampu membuat soal online. Demikian juga oleh Mukharomah (Cara et al., 2021) telah memberikan pelatihan dengan 
1117 Pelatihan Pembuatan Soal dengan Google Drive Untuk Pembelajaran Jarak Jauh - Anita Debora Br. Simangunsong

DOI: https://doi.org/10.31004/abdidas.v2i5.435

pemanfaatan google form di kalangan guru SDN 3

Makarti Jaya.

Tujuan dari kegiatan ini adalah pelaksanaan evaluasi siswa di masa pandemik ini lebih praktis dengan meningkatkan wawasan dan keterampilan guru dalam menggunakan Aplikasi Google Form.

\section{METODE}

Kegiatan pelatihan ini melibatkan guru-guru SMK Yapim Taruna Sei Rotan sebagai peserta. Dimana kegiatan pelatihan ini dilakukan selama 2 hari dan dimulai dari tanggal 13-14 Januari 2021.

Metode pelaksanaan kegiatan ini dilaksanakan menggunakan media online. Kegiatan ini diawali dengan sosialisasi, dan pelatihan. Adapun bentuk-bentuk kegiatan sebagai berikut. a. Presentasi, dilakukan di hari pertama tanggal 13 Januari 2021. Diawali dengan penjelasan tentang;1) Fungsi dan manfaat Google Form untuk kegiatan pendidikan, 2) komponen dan alat-alat yang yang diperlukan dalam pembuatan kuis ataupun kuesioner, dan 3) Prinsipprinsip pembuatan kuis dan kuisioner. b. Praktek, dilakukan di hari kedua yaitu tanggal 14 Januari 2021. Setelah semua peserta memahami komponen dan prinsip-prinsip penggunaannya dengan baik, lalu masuk kepada sesi latihan praktek membuat kuis dan kuisioner online meggunakan Google Form, teknik meyimpannya dalam Google Drive, teknik membagikan ataupun menyebarkan kuis ataupun survei online melalui email, media sosial. c. Tanya Jawab. Semua peserta pelatihan ini diberikan kesempatan untuk bertanya tentang sesuatu yang belum jelas, baik yang telah disampaikan dalam presentasimaupun hal-hal lain yang berkaitan dengan praktik pembuatan kuis atau lembar survei online menggunakan Google Form.

\section{HASIL DAN PEMBAHASAN}

Kegiatan pengabdian ini diawali dengan analisis kebutuhan mitra (guru-guru) di SMK Yapim Taruna Sei Rotan yang terletak di Jl. Medan Batang Kuis Dusun VIII, Sei Rotan, Kec. Percut Sei Tuan, Kab. Deli Serdang.

Hasil kegiatan pelatihan penggunaan Google Form sebagai media pembelajaran jarak jauh dilakukan secara daring, disusun dan hasil kegiatan tersebut dapat dijabarkan sebagai berikut:

Sesi pemaparan materi, diikuti oleh guruguru SMK Yapim Sei Rotan sangat antusias menerima materi yang disampaikan. Saat pembelajaran berlangsung, terjadi interaksi yang baik antara peserta dan pemateri.

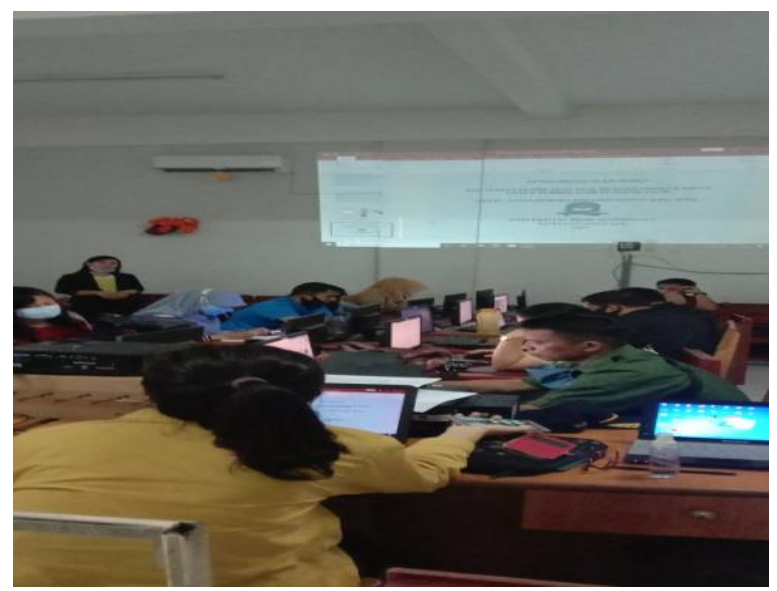

Gambar 1. Memberikan Materi

Sedangkan sesi kedua adalah praktik langsung membuat kuis dan kuisioner online meggunakan Google Form, teknik meyimpannya 
1118 Pelatihan Pembuatan Soal dengan Google Drive Untuk Pembelajaran Jarak Jauh - Anita Debora Br. Simangunsong

DOI: https://doi.org/10.31004/abdidas.v2i5.435

dalam Google Drive, teknik membagikan ataupun menyebarkan kuis ataupun survei online.

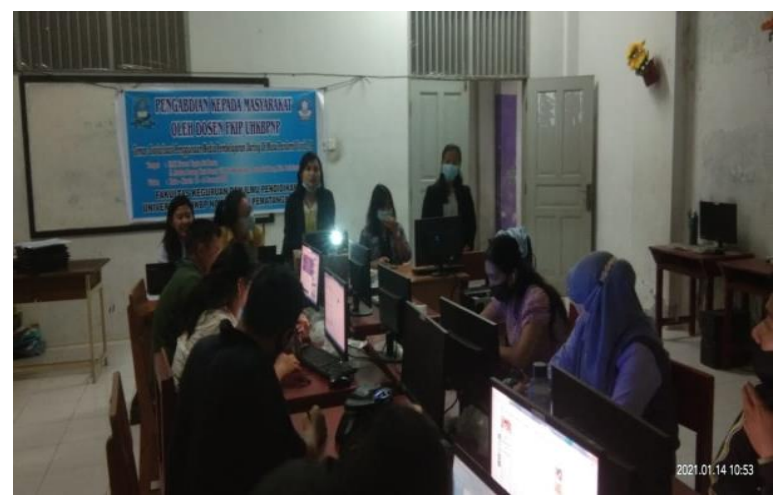

Gambar 2. Peserta Sosialisasi

Selama kegiatan, peserta pelatihan tampak aktif dan sangat tertarik untuk mencoba membuat media media penilaian atau kuis online menggunakan Google Form. Karena aplikasi ini memiliki tampilan sederhana dan sangat bermanfaat untuk memberikan penugasan dan kuis secara online kepada peserta didik.

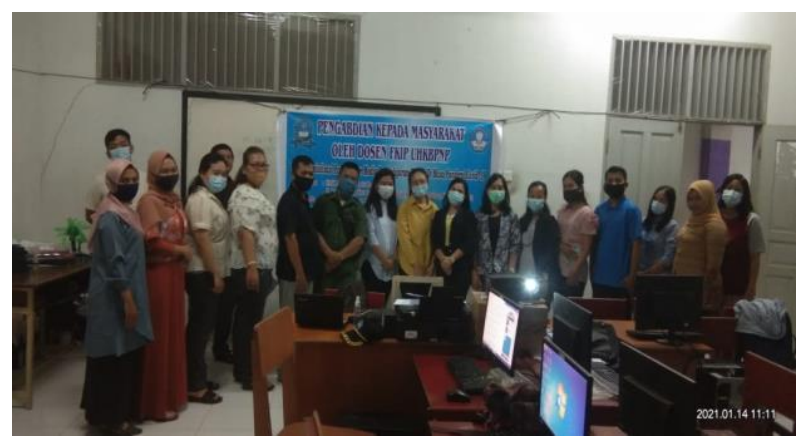

Gambar 3. Peserta Sosialisasi

Evaluasi kegiatan dilakukan dengan melihat hasil google form yang dibuat oleh guru-guru di SMK Yapim Taruna Sei Rotan Dari peserta yang telah membuat google form, mendesain google form terlihat sangat antusias serta hasil yang dibuat dengan berbagia macam tema yang unik dan menarik.

Penggunaan media google form dalam evaluasi dapat dilakukan secara optimal dan maksimal di dalam pembelajaran Jarak jauh/daring seperti saat ini. Pengajar atau trainer dapat memanfaatkan Google Forms untuk melakukan quiz/tes terhadap murid atau peserta training melalui device yang mereka gunakan (smartphone, tablet atau laptop). Google Forms gratis, tidak ada biaya untuk menggunakan produk tersebut. Begitu banyak manfaat dari google form salah satunya kita manfaatkan sebagai media evaluasi.

Google form merupakan media paling efektif untuk proses pembelajaran. Hal tersebut terlihat pada faktor situasi kondisi siswa yang memiliki kesulitan jaringan internet. Penggunaan google form sangat mudah dan efektif dengan keterbatasan kondisi siswa. Siswa masih dapat mengumpulkan tugas siswa walaupun koneksi internet terkendala.

Hasil kegiatan pengabdian ini berhasil dengan baik karena terlihat dari antusias dan pemahaman guru-guru SMK Yapim Taruna Sei Rotan dalam pelatihan pembuatan google form.

\section{SIMPULAN}

Peserta pelatihan menerima dan mempraktekkan teori yang disampaikan dengan baik. Tujuan utama kegiatan ini sudah tercapai dengan memberikan materi dari pelatihan pembuatan soal dengan google drive dengan fitur pembuatan kuis yang bisa di setting pada penggunaan google formulir dengan batasan waktu. Dengan kegiatan ini peserta mampu 
1119 Pelatihan Pembuatan Soal dengan Google Drive Untuk Pembelajaran Jarak Jauh - Anita Debora Br. Simangunsong

DOI: https://doi.org/10.31004/abdidas.v2i5.435

membuat soal online untuk para siswa dalam masa pandemi.

\section{UCAPAN TERIMA KASIH}

Tim pengabdian mengucapkan terima kasih kepada Ibu Kepala Sekolah SMK Yapim Taruna Sei Rotan dan kepada guru-guru sebagai Peserta Pelatihan Masyarakat di Sei Rotan.

\section{DAFTAR PUSTAKA}

Basar, A. M., Islam, P. A., Nurul, S., Cikarang, F., \& Bekasi, B. (2021). Problematika Pembelajaran Jarak Jauh Pada Masa Pandemi Covid-19 ( Studi Kasus Di SMPIT Nurul Fajri-Cikarang Barat - Bekasi) A . Pendahuluan Kemampuan, Sikap, Dan Bentuk-Bentuk Tingkah Laku Yang Bernilai Positif. Hal Itu Untuk Pencipta . Pendidikan S. 2(1), 208-218.

Cara, P., Dan, M., \& Melakukan, C. (2021). Pelatihan Cara Mudah Dan Cepat Melakukan Evaluasi Dengan Pemanfaatan Google Form. 4(1).

Hanum, N. S. (2013). Keefektifan E-Learning Sebagai Media Pembelajaran ( Studi Evaluasi Model Pembelajaran E-Learning Smk Telkom Sandhy Putra Purwokerto ) The Effectiveness Of E-Learning As Instructional Media ( Evaluation Study Of E-Learning Instructional Model Insmk Telkom . 3, 90102.

Marlina, S., Leba, R., Lina, N., \& Habeahan, S. (N.D.). KOMMAS : Jurnal Pengabdian Kepada Masyarakat Universitas Pamulang Pelatihan Model Pembelajaran Jarak Jauh Berbasis Google Form Sebagai Media Pembelajaran Universitas Musamus Merauke KOMMAS: Jurnal Pengabdian Kepada Masyarakat Universitas Pamulang. 42-46.

Prawiyogi, A. G., \& Purwanugraha, A. (N.D.). Efektifitas Pembelajaran Jarak Jauh Terhadap Pembelajaran Siswa Di Sdit Cendekia Purwakarta. 